\title{
THE POLITICS OF FEMALE IDENTITY: AN INTERVIEW WITH JANE SHERRON DE HART
}

\section{Jane E. Simonsen}

This interview took place on September 26, 1996 while Jane De Hart visited the University of Iowa as an Ida Beam Distinguished Visiting Professor. Currently at the University of California at Santa Barbara, De Hart's work includesThe Federal Theatre, 1935-39: Plays, Relief, and Politics ( 2nd ed., 1971),Sex, Gender, and the Politics of ERA: A State and the Nation (1990), and the co-editorship of four editions of the women's history text Women's America: Refocusing the Past (4th ed., 1995). While in Iowa City, De Hart presented two lectures, "Containment at Home: Boundaries and the Body Politic" and "Exclusion from Home: Black Welfare Mothers as 'Other,"' based on her current research on national identity in Cold War America. She also presented the keynote address, "Suffragists' Hopes/Feminists' Strategies: Women and Electoral Politics" at the University of Iowa conference "The Uses of Suffrage: Women, Politics, and Social Change Since 1920." Here she discusses some of the ways race and gender identities and constructions of difference have influenced and been influenced by federal politics and policy.

Your work in both Sex, Gender, and the ERA and in your forthcoming book on the politics of national identity reveal ways in which race and gender overlap. 'This overlap was evident in the preliminary chapter of Sex, Gender, and the ERA, which dealt with suffrage, and in the more recent struggle over ERA. It was also prominent in your lecture on contemporary welfare politics and the racialization of AFDC mothers. What first alerted you to the role of race in the debate over ERA?

One of the advantages of working on very recent history is the opportunity to be a participant observer. When I began research on the ERA ratification struggle in 1977, I attended the legislative hearings at which supporters and opponents testified for and against ratification with the plea, "Please don't desexigrate us." 2 Of course, the word isn't in the dictionary, but I thought it was quite revealing because it so clearly linked this woman's concerns about federal gov- 
ernment policies associated with racial desegregation and her apprehensions about future measures relating to sex-based discrimination. Another telling example was a letter to U.S. Senator Sam Ervin, written when ERA was still being debated in the Senate, that consisted of one sentence: "Forced busing, forced mixing, forced housing. Now forced women! No thank you!" 3 These women (and many men) were thoroughly convinced that an interventionist government that would force the integration of residentially segregated housing, public facilities, dictate whom businesses could hire through affirmative action, and "destroy" neighborhood schools by busing simply could not be trusted. My initial inclination was to think these concerns were distinctively Southern the old states' rights stuff - until I saw the same arguments voiced in Massachusetts in debates over passage of a state ERA.

This notion of "forced women" suggests another concern of ERA opponents: fears that an equal rights amendment would make them "become men." Many of us think of liberal ERA activists, most of whom were feminists, as basing their politics on womanhood. Yet the conservative anti-ERA women you describe in your book are also basing their politics on a concept of womanhood, although a different one. In some ways ratificationists never took this into account. They assumed that passage of ERA would produce gender neutrality in the law. Opponents foresaw something much bigger - cultural revolution. Why weren't ERA supporters more perceptive about opponents' apprehensions? If they had been, could they have countered them more effectively?

How to neutralize the opposition's apprehensions is a critical question that supporters of state ERAs in Iowa and elsewhere must surely be asking themselves. You are right. Different conceptions of womanhood are involved because the two groups attach different measures of significance to female difference. Ratificationists were liberal feminists for the most part. Like radical feminists, they tended to minimize female difference, believing that men and women were more alike than different and should be treated the same, except when biological difference really mattered. Antiratificationists/antifeminists, like many "difference" feminists, maximized and valorized female difference. Anti-ERA women also had difficulty separating sex and gender. They saw gender neutral law not as stripping away the cultural meanings attached to sexual difference that penalized women; rather, gender neutrality meant denying them the privileges and protections of womanhood. It meant denying them the right to be women and forcing them to "become men." As an attack on their very identity, gender neutrality was perceived as the basic obliteration of self.

I'm not sure whether it would have been possible for ratificationists to address these fears even if they had understood them. What supporters heard from opponents were their fearful projections of the dire consequences of ratification: loss of exemptions from military service if a draft were reinstated (on that point supporters agreed), loss of other legal privileges, sexual integration of public restrooms, decriminalization of rape, legitimization of homosexuality, further entrenchment of abortion as an option, destruction of the family, and so 
on. Supporters were appalled at the exaggeration and misinformation in these charges and tried to respond. But answering the charges "logically" and "factually" never addressed the core concerns of opponent women.

The sense of women's vulnerability is palpable in the consequences they project onto ERA legislation. They fear that because of their sex they will be more vulnerable to rape and abuse, especially in the workplace or in the military.

Absolutely. The military represents the greatest danger. But they also feel vulnerable in the workplace. Equality has historically meant "equality of opportunity" to Americans - equal opportunity to compete economically. What feminists saw as broadening of opportunities and options, antifeminists saw differently. They were keenly aware that as women they lacked the socialization and possibly the skills that would make them effective competitors in the workplace. Feminists, whom antifeminist thought were aggressive and relished competition, were not only perceived to be behaving like men, but were "becoming" men. In doing so, they were setting a standard to which all women would have to conform - and in places that were potentially dangerous to women.

Separation of space by gender - this goes back to deeply rooted ideas that women work in the home and men in the public realm. I find it interesting that, although many antiratificationist women were already working outside the home, in some way the loss of the idea of separate spheres seems disadvantageous to them. I'm struck not only by how closely our conception of equality is tied to work, but also to our conception of citizenship. You touched on work and citizenship in your lecture on welfare mothers.

Judith Shklar's wonderful little book, American Citizenship, makes the point that although the constitution says nothing about earning in relation to citizenship, Americans have always linked the two. ${ }^{4}$ Earning provides the independence and public respect that have historically entitled one to full and equal citizenship. I think this emphasis on earning helps to explain why Americans have had greater difficulty than Europeans in embracing the concept of social citizenship - the right of all citizens to a basic level of economic security and welfare - not welfare in the sense of charity or relief, but in the larger sense of that term.

It's ironic that welfare has become such a pejorative term, since much of the early welfare legislation was designed to protect women and children and to maintain families. Yet we now have this picture of the welfare mother as a single mother with children born out of wedlock; it is at odds with the traditional ideal of family which those laws were designed to protect. How did this fictive identity of the welfare mother develop?

That requires a much more complex and nuanced explanation than we have time for. The place to start is with the fact that we have always discriminated between the "worthy poor" and the "unworthy poor" where some form of pub- 
lic assistance is concerned. When Mothers' Pensions were inaugurated in the early years of the 20th century, the goal was to assist "worthy" mothers with dependent children. That meant for the most part widows who were morally upright: who were not cohabiting with men who were not their husbands and who did not have illegitimate children. The women whom local administrators determined met that criteria were overwhelmingly white and judged to be "good" mothers by middle-class standards. As Mothers' Pensions eventually evolved into Aid to Families with Dependent Children [AFDC], these rules remained in effect. Welfare was intended not only to provide an economic safety net but to send messages to the poor as well as to the larger public about dominant norms with respect to work and family. Concerns about frugality and morality required that welfare rolls remain small. Racist and gendered assumptions about work and family ensured they be kept white. As a result, needy women of color were disproportionately relegated to the ranks of the unworthy until the 1960s.

The civil rights movement, the welfare rights movement, War on Poverty, and the Supreme Court changed all of that. As welfare and other poverty programs became accessible to women of color, their numbers increased. So did the number of whites on welfare, for that matter. The problem was that, by the 1970 s, when the backlash against the "excesses" of the 1960s set in, black illegitimacy, unemployment, crime, and welfare continued to rise. And don't forget the riots. Many whites felt that the very people who were rioting were beneficiaries of their hard-earned tax dollars. Federal largess, race, and moral breakdown became impossible to disentangle. In this climate, the stereotype of the black welfare mother unwilling to work or to wed was a wonderful weapon that old-line conservatives as well as neoconservatives could use to discredit Johnson's social programs and, of course, welfare itself - which the public had come to equate with AFDC. As a symbol, the black welfare mother encapsulated a number of disturbing developments: prolonged welfare dependency, rising illegitimacy, increasing numbers of female-headed households. Matrimony, paternal responsibility, and the work ethic all seemed to be at risk.

Does the culture of poverty thesis relate to this stereotype? Does this emphasis on deviant behavior have consequences?

The pathologizing of the poor generally and of the black matriarch in particular did indeed contribute to the stereotype and it certainly has had consequences. When Oscar Lewis's culture of poverty thesis was first debated in the 1960s, critics charged that, in trying to explain the inter-generational behavior of the poor, Lewis shifted the emphasis from poverty to culture and, in doing so, deflected emphasis from the structural causes of poverty to the deviant behavior of the poor. Liberals - and I would include Daniel Moynihan in that group in the 1960s when the Moynihan Report was published - would argue that the deviant behavior was all the more reason for compensatory programs for the black poor that would break the cycle of poverty and the deviant behavior associated with it. But neoconservatives and old-line racial conservatives were able to use it for 
their own purposes - to support the status quo.

If you look at Congressional debates over welfare reform since the failure of Nixon's family assistance plan, you will discover a real shift in emphasis. There is less and less discussion of how to deal with the structural causes of poverty that would require additional spending - and more focus on changing the deviant behavior of the poor. This shift has become quite apparent in the welfare debates of the '90s. We will use policy to change behavior: Workfare to reinforce the work ethic, family caps to cut down on illegitimacy by cutting off aid to children born out of wedlock to mothers on welfare. We will enforce parental responsibility by going after dead-beat dads. While we can all agree that the old welfare system needed reform and that the work ethic and parental responsibility are to be encouraged, these "remedies," many social scientists argue, are really symbolic rather than substantive. How can you enforce child support when fathers are unemployed and there are simply no jobs in the inner city or impoverished rural areas? How can family caps work when studies show no evidence that women on welfare are having babies in order to increase their welfare checks?

In focusing on the stereotype of the black welfare matriarch, one of the things that I am exploring is the extent to which she has come to symbolize not only the AFDC mother (never mind that most AFDC mothers are white) but, inasmuch as AFDC has come to symbolize welfare, the poor generally. To the extent that she does symbolize the poor, they have become racialized and morally stigmatized. This further diminishes their claim on the state for assistance.

In Sex, Gender, and the Politics of ERA, you relied very much on interviews. We heard voices of women from both sides; it was almost as if you were recreating the conversation between them. What was so enlightening was that the book made real the concerns of both supporters and opponents, particularly the fears of opponent women. In the debates over welfare, the voices we hear are those of politicians and policy makers, not the women on welfare who seem to remain voiceless. Do you intend to interview welfare mothers?

I would love to do some interviews and incorporate women's voices into the welfare chapter. They may not be aware of many of the issues we have talked about, but they do feel that they have no voice and some do have a real sense of their own delegitimization and powerlessness. That perception is an accurate one. Many of the institutions and programs that were created during the War on Poverty to enhance their voices no longer exist - legal services, for example.

I have to add that interviews - we did over 100 in the ERA study - can be very time-consuming and sometimes very difficult to set up. Interviewing anti-ERA women proved enormously challenging for a number of reasons I discussed in an article in The Journal of American History. ${ }^{5}$ I'd like to think that in spite of opponents' distrust, we make the case for them consistent with their own position and in ways that illuminate their real concerns.

A lot of graduate students have concerns that what we are doing at universities 
is not going to change society. If we do a study on welfare mothers, for example, what impact might it have on policy? How do we convince people that stereotypes, while embodying some measure of truth, have negative and very real consequences for women and their families? How do you say to a politician, "Look, much of what you are doing is symbolic and does not deal with the structural causes of poverty?"

You have identified an enormous source of frustration not only for graduate students, but for all of us. The research assistant who was doing research for this chapter started out as an economic historian with a somewhat conservative bent. He believed the cuts Reagan was making in various domestic programs were a useful approach to reducing the deficit and were not "political." After a summer of gathering data, which included Congressional debates on welfare reform for the past two decades, he walked in one day and said, "I think I've had an epiphany!" His views on Reagan and welfare had changed dramatically. His current concern is how to write history that policy makers will read and that will make a difference. The memory of policy makers is so short and often inaccurate that we really need good histories. Unfortunately, in the political climate of recent years, it is harder to have that sense of possibility that one's research can make a real difference.

Your own article, "Equality Challenged," is an example of work that ties into what is going on today. ${ }^{6}$ You tried to expose some of the complexities of dealing with sexual difference in the law in areas such as pregnancy and how to figure this in terms of equality and difference.

The difference dilemma is an old and vexing problem. In the first wave of feminist litigation on sex discrimination, feminist legal strategists, notably Ruth Bader Ginsburg, who was then a young professor at Columbia University Law School, proceeded on the assumption that equality could be achieved through the same treatment of both sexes. It was assumptions about gender differences that accounted for much of that discrimination in the first place. But feminist legal scholars and strategists soon discovered that the problem was more complex. How to treat pregnant workers provides a perfect example. Is equality achieved by treating men and women workers the same, making pregnancyrelated disability no different from any other disability? The answer seemed to be yes.

But what if you are an employee of a small company that has no disability programs for its workers and you become pregnant and it is a difficult pregnancy and there are complications? Taking time off may cost you your job. Even if you are later reemployed by the same company, you may have lost seniority and/or benefits. Aware that this is a real problem for many women, the California legislature stipulated that companies that had no disability policy must provide pregnancy disability for its female employees. Is this special treatment for women? Yes, and male employees objected. The case, California Federal Savings and Loan Association v. Guerra, eventually made its way to the 
Supreme Court. Thurgood Marshall wrote the majority opinion which upheld the California law. The state of California, in treating women differently, was not providing special favors. Rather, he argued, it was simply trying to make it possible for women to have a family and also have a job in the same way that men have always been able to have both. As legal scholar Martha Minow would say, the Court tried to take into account "the difference that difference makes."7

Feminist legal scholars really wrestled with the difference dilemma and have tried to reconceptualize it. Their work has made it clear that achieving equality based on rights theory is a much more complex and problematic task than it seemed to be in the late ' 60 s and early ' 70 s.

There seem to be a lot of layers to negotiate with respect to equality.

Absolutely. Feminist scholars of color have done an immense service by making us aware of how multiple forms of oppression interact and of the magnitude of the changes that must occur. In my own work, I'm beginning to explore how hierarchies of gender, race, and sexuality resist change by virtue of their embeddedness in constructions of national identity. It's a different focus for me and a terribly exciting one. The Ida Beam lectures have provided a wonderful opportunity to work through some of the issues with others before my ideas have really jelled. I have gotten such useful feedback from graduate students as well as faculty. You have some impressive students here who really know how to make the scholarly enterprise a collective one.

\section{Notes}

${ }^{1}$ Donald Mathews and Jane Sherron De Hart, Sex, Gender and the Politics of ERA: A State and the Nation (New York: Oxford University Press, 1990).

${ }^{2}$ Mathews and De Hart Sex, Gender, p. 172.

${ }^{3}$ Jane Sherron De Hart, "The New Feminism and the Dynamics of Social Change," Women's America:

Refocusing the Past. Ed. Linda K. Kerber and Jane Sherron De Hart, 4th ed. (New York: Oxford University Press, 1995), p. 554.

${ }^{4}$ Judith N. Shklar, American Citizenship: The Quest for Inclusion (Cambridge: Harvard University Press, 1991), ch. 2.

5 "Oral History and Contemporary History: Dispelling Old Assumptions," Journal of American History 80 (September 1993), pp. 582-95.

6 "Equality Challenged: Equal Rights and Sexual Difference," Journal of Policy History 6:1(1994), pp. 40-72.

${ }^{7}$ Martha Minow, Making all the Difference: Inclusion, Exclusion, and American Law (Ithaca: Cornell University Press, 1990). 